\title{
Social Capital: A Factor in Region's Sustainable Development
}

\author{
Tatiana A. Guzhavina ${ }^{1}$, Albina A. Mekhova ${ }^{2}$
}

\begin{abstract}
The views on sustainable development demonstrate a new trend - a gradual transition from the macro-level to the meso- and micro-level. This interpretation is typical for the so-called cluster approach to sustainable development. The cluster approach is based on the principles of corporate citizenship and is often used to study the formation mechanisms of sustainable development in the region. Within the framework of this approach, non-material social resources that contribute to the region's competitiveness are of particular importance. The authors believe it would be efficient to explore these resources through the concept of social capital. Modern research shows that social capital is an intangible factor and a resource that affects the economy and social welfare in general. The article presents the author's view on some conceptual issues underlying the study of social capital. The efficiency of applying the concept of social capital to study the problems of regions' sustainable development is determined. A number of proposals on empirical investigation of the role and importance of regional social capital of the region are made.
\end{abstract}

Keywords: sustainable development, social capital, region, indicator model

\section{Problem Statement}

Within the framework of the usual triad approach to the concept of sustainable development which includes three aspects - environmental, economic, and social - new trends have appeared - a gradual transition from the macro- to the meso- and microlevel. This interpretation is typical for the so-called cluster approach to sustainable development. The name is explained by the fact that sustainable development, according to the authors of the approach, is carried out through the formation of clusters geographically concentrated groups of interconnected companies and related organizations in certain competitive fields [Porter, 2006]. The cluster approach is based on the principles of corporate citizenship and is often used to study the mechanisms of region's sustainable development. Within the framework of this approach, nonproduction non-material factors contributing to the region's competitiveness are of particular importance. Nowadays it has become clear that the role of relations based on how individuals and the society as a whole are organized and interact to achieve certain results, is enormous. Such relations and their socially significant effects are called social capital. Social capital is the resource of development that affects economic growth, social welfare, efficiency of social programs and much more. This raises the question of how, by what means can region's social capital be accumulated. 


\section{Conceptualization of the Definition of Social Capital}

In science there are different points of view on interpreting social capital. This creates some uncertainty in the theory. The development of the theory of social capital is primarily associated with the names of Pierre Bourdieu, James Coleman, Robert Putnam, and Francis Fukuyama. It is thanks to them that we understand that social capital is a complex concept covering several dimensions: sociological, economic, and political.

The concept of social capital has deep theoretical roots. Its origins can be traced back to the theoretical constructs created by the sages of the 19th century. The concept reflects many basic provisions of Marx theory of capital. The theory considers capital as a social relation [Marx, Engels, 1960] occurring during the interaction of a hired worker and a bourgeois as the latter begins to use human labor. This gave Marx an opportunity to consider capital as a self-expanding value. But the capital closely linked to investment of resource can only belong to the bourgeoisie, while employees cannot increase the value of their labor, i.e. cannot possess capital. Later, the interpretation of capital proposed by I. Fisher became widespread in economic science. Fisher believed that capital is what generates a flow of services that turn into an inflow of income. He proposed to use the value of generated income as a method for assessing capital [Fisher, 2007].

The emergence of the neoclassical theory of capital led to the expansion of the concept. G. Becker formulated the concept of human capital [Becker, 1975]. This type of capital was represented by an employee's personal characteristics such as health, physical condition, energy supply, knowledge, professional experience, and qualifications. All these characteristics give individuals an opportunity to benefit from them and use them to their advantage.

In the framework of postmodernism, the concept was further expanded. P. Bourdieu defined capital as accumulated labor which makes it possible to assign social energy. Bourdieu widely used the term; he enriched the concept by giving it new characteristics and revealing new forms. They were: economic, cultural, and social capital [Bourdieu, 2002]. Each form has its specific features. Thus, material capital is tangible and is represented by material objects. Human capital is manifested through the achievements of an individual obtained with the help of their health, intelligence, skills, and abilities. Bourdieu connected human capital to the human body [Bourdieu, 2002]. These are all tangible forms of capital that can be grouped together and designated as material forms. In contrast, social capital is considered within the boundaries of non-material forms. It is intangible, which is explained by the different nature of this type of capital. It is generated by the relations where the actor enters the communication process. These are the relations of mutual acquaintance and recognition formed by joining the group, which "gives its members support in the form of collective capital, reputation" helping them receive loans in every possible way [Bourdieu, 2002]. This is its fundamental difference from material and human capital. Another difference is related to ownership of capital. Of all identified forms, only social capital is a public good and cannot be the property of a subject using it. The nature of this property lies in the way social capital is generated. Being generated in the networks of relations, social capital belongs to all participants of these networks. Nevertheless, it would be a mistake to think that the interpretation of social capital as a public good enables any individual to use it. This opportunity is only 
given to those who are members of the network. The forms of capital are the basis for building a certain type of social relations.

Social capital, which includes social relations, mutual exchange and mutual assistance, provides a person with a certain social position (status) in the emerging social structure. This status can be recognized both formally and informally. Its significance is that it provides access to resources available to community members surrounding the individual. Bourdieu believed that social capital is of symbolic nature, that it can be identified through membership in any group. In fact, this is nothing but a kind of social practice. Analyzing the identified forms of capital and their ability to flow from one to another, Bourdieu described it as a dynamic resource [Bourdieu, 2001].

Further in-depth analysis of social capital is contained in works by J. Coleman, who put forward and justified the role of trust, which is the basis for relations that generate the social capital of an individual [Coleman, 1994]. It is trust that distinguishes social capital from other types of capital. Trust is a necessary element of any cooperation. In our opinion, Coleman's approach traces the connection with the idea of social solidarity expressed by E. Durkheim.

When elaborating the concept, the researchers faced the question of the role of citizens' public associations. Studying public associations and the results of their activities, R. Putnam, one of the founders of the concept of social capital, considered them as an effective way of generating social capital. He noted that it is thanks to them that inclusion in public life is ensured, contacts and ties are expanded, and interaction standards are developed and strengthened. According to the definition of R. Putnam, social capital represents "connections among individuals, social networks and standards of reciprocity and trust that arise from them" [Putnam, 2001]. Thus, R. Putnam, studying the life of a community through activities of associations created by individuals, managed to identify the value of network interaction.

The study of social relations demonstrated their importance for growth, development, and competition. Increased attention to social capital reflected primarily in the number of studies marks a shift towards studying intangible resources. According to some estimates, intangible assets in the national wealth of developed countries comprise more than $80 \%$, while in Russia this figure is only about 16\% [Boldov, 2010].

We have studied and compared many definitions of social capital. All the authors say that the presence of the term capital in the category demonstrates that it should be interpreted as a non-material resource that helps preserve or boost material resources. This resource is contained in evolving relations that form social connections providing access to various resources for individuals and groups. Social capital is embedded in social relations and social structures that can be mobilized when an actor wants their deliberate actions to be more likely to be successful. We combined these meanings into a single concept. We consider social capital, first, as networks of social relations characterized by standards of trust and reciprocity, the level of involvement in them, and, ultimately, external effects, results generated by social interaction within interpersonal networks and associations based on trust, shared standards and values, useful for the society and social groups (in the specific context of the article - for a region) [Afanasev, Guzhavina, Mekhova, 2016]. It is of fundamental importance that none of these components can be considered as social capital in isolation. 


\section{Connection between Social Capital and Sustainable Development}

Thus, social capital is an intangible, non-material resource without which it is impossible to ensure economic development. The researchers have found out that the high level of associative life, trust, standards of reciprocity and civil cooperation is strongly correlated with the level of per capita income in the region. The empirical research into the topic of the impact of social capital on economic growth was conducted by Knack and Keefer [Knack, Keefer, 1997], who built a regression model linking the economic growth of states with the level of trust, standards of ethics and membership in associations. The researchers showed that trust and civil cooperation have a significant impact on economic activities. S. Beugelsdijk and S. Smulders [Beugelsdijk, Smulders, 2009], analyzing the properties of the model, conclude that the connection between economic growth and social capital depends on the system's internal characteristics and may have different directions for different societies and periods of development, namely, for more developed and less developed countries. The features of the current state can be identified based on empirical analysis. T. Shapovalova systematizes the positive effects of social capital for economic growth [Shapovalova, 2013]. She notes the impact of social capital on reducing transaction costs, creating an attractive investment environment, and preventing and combating fraud in economic operations. Social capital improves the exchange of information flows and accelerates the spread of innovation. Social capital serves as a guarantee for business entities in risky but potentially more profitable economic activities.

The link between social capital and sustainable development is evident in the fact that, during an economic crisis, social capital is a protective factor. Social capital and social networks might present a network protecting against adverse effects of rapid macroeconomic changes. Thus, Jóhannesson, Skaptadóttir and Benediktsson demonstrate that the priority in determining the ability of a person to cope with an economic crisis is the prevalence of social networks, the ability to innovate and a strong sense of both individual and social identity [Jóhannesson, Skaptadóttir, Benediktsson, 2003]. In some cases, a period of crisis can lead to greater social cohesion and can even generate new relations that improve overall social capital when communities find innovative ways to overcome problems. The empirical evidence of the impact of social capital on the region's sustainable development rests upon the problem of measuring social capital.

\section{Indicator Model}

In recent years, the issue of measuring social capital has been actualized by the objectives of forming the mechanisms for regions' sustainable development. C. Marsch was the first to propose to measure social capital at the regional level. He developed a method for measuring the social capital index [Marsh, 2000]. One of the most interesting domestic studies is the study by L.I. Polishchuk and R.I. Menyashev Polishchuk, Menyashev, 2011]. They established a positive relation between the efficiency of city administrations, open social capital, and civic culture. In their opinion, modern social capital in Russia possesses significant reserves which are very unevenly distributed between the country's cities and regions. L.I. Polishchuk claims that social capital is an 
exclusively "local" product; it fixes the problem arising from high values of social capital for regional development: "It is only necessary to create favorable conditions for its reproduction and accumulation, supporting the educational system (including at public expense), opening opportunities for public initiatives and self-organization in business and everyday life of the citizens" [Polishchuk, 2011]. We agree with the opinion of L.I. Polishchuk regarding the relevance of the regional aspects of social capital.

We have developed an indicator model for measuring social capital. The basic list of model components is laid in the definition. Social capital is firstly referred to as the presence of networks of social relations based on trust and characterized by common standards and values; as well as the level of people's involvement in them; second, as external effects and results useful for the society and social groups (in our context - for a region) and generated by social interaction within these networks and associations based on trust, common standards and values. Thus, the main components of the model of social capital are:

1. Trust

2. Networks as informal interpersonal relations

3. Networks as involvement in public organizations, groups

4. Solidarity, willingness to work together;

5. The feeling of being able to influence the situation in the family, house-yard, city, etc.;

6. Values, attitudes.

We consider social capital as an integral social indicator which helps assess the state of social relations. At the moment, however, there is no single established way to determine the necessary and sufficient indicators for identifying its properties in a particular community.

There are also difficulties in choosing indicators for analyzing the state of social capital, as well as indicators for their measurement. Since the concept of social capital can be characterized as a generalizing concept, we distinguish a set of operational concepts within it such as trust, networks, values and standards, solidarity, and the ability to influence the situation. They are considered as variables characterizing social capital of a community. These variables are disclosed through a system of social indicators. The content of the indicator is not arbitrary. It necessarily corresponds to the content of the measured index which is its particular manifestation. The indicator is an expression of the index's attribute.

Based on the results of selection, a model of variables of existing types of social capital of the region's population was built, which is demonstrated in Figure 1. 


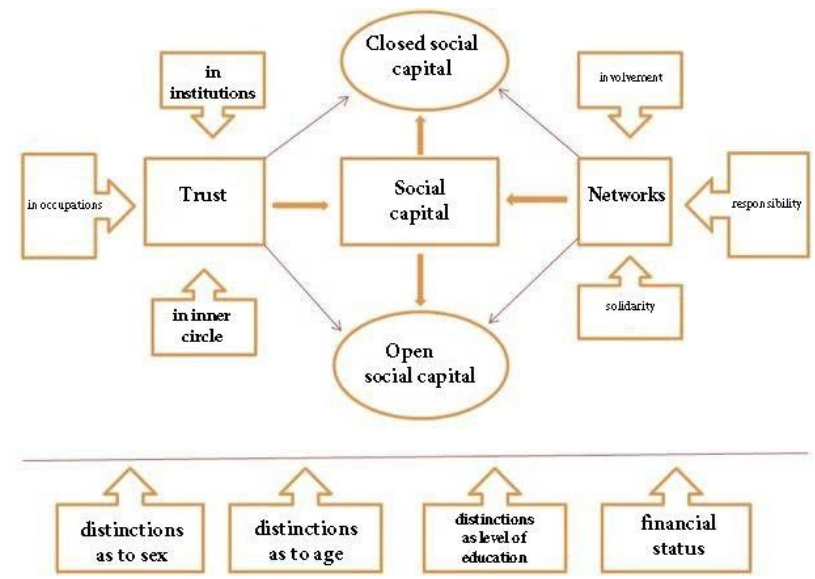

Figure 1. Model of variables forming types of social capital

One of the methods of measurement can be a sociological survey of the population. In this case, the respondents' answers will be indicators of the main components of social capital. According to the survey, the population of the region is divided into groups of carriers of social capital of different levels - from high to low. The region's social capital can be judged by the share of people with a high level of social capital.

The developed tools for sociological survey include sets of questions for each component of social capital. Index method is used for data analysis. An individual index is calculated for each question. According to the general complex model, the first additive indicator model of social capital is built. A complex index is calculated for each respondent, consisting of ten private indices; an average index is concluded, according to which each respondent is ranged in a group with a particular level of accumulated social capital.

The index of social capital of each respondent is calculated according to the formula:

$\mathrm{I}_{\mathrm{SC}}=\left(\mathrm{I}_{\text {trust }}+\mathrm{I}_{\text {influence }}+\mathrm{I}_{\text {values }}+\mathrm{I}_{\text {networks }}+\mathrm{I}_{\text {involvement }}\right) / 5$,

where

$\mathrm{I}_{\text {trust }}=\left(\mathrm{IT}_{\text {ip. }}+\mathrm{IT}_{\mathrm{PI}}+\mathrm{IT}_{\text {inst }}+\mathrm{IT}_{\mathrm{PG}}\right) / 4$,

where $\mathrm{T}_{\mathrm{ip}}-$ interpersonal trust

$\mathrm{T}_{\mathrm{PI}}-$ trust in political institutions

$\mathrm{IT}_{\text {inst }}-$ trust in public institutions

$\mathrm{IT}_{\mathrm{PG}}-$ trust in professional groups,

$\mathrm{I}_{\text {influence }}=\left(\mathrm{II}_{\text {close }}+\mathrm{II}_{\text {med }}+\mathrm{II}_{\mathrm{far}}\right) / 3$,

where $\mathrm{II}_{\text {close }}$ - influence on the situation in a family, house, yard

$\mathrm{II}_{\mathrm{med}}$ - influence on the situation at work, in a settlement, city

$\mathrm{II}_{\text {far }}-$ influence on the situation in a region, country,

$\mathrm{I}_{\text {values }}=\left(\mathrm{I}_{\text {adaptation }}+\mathrm{I}_{\text {Responsibility locus }}+\mathrm{I}_{\text {innovation practice }}+\mathrm{I}_{\text {ready associations }}\right)$

As a result, all respondents were divided into five groups depending on the obtained index, that is, the level of accumulated capital. People with the lowest level of social capital who mainly chose options "do not trust" and "can not influence" were included in the first group which we conditionally designate as the lowest level of social capital, 
where the index is over 1 and under 2. Conditionally it is Type 1.

The second group includes people with a higher average index who we view as people with low closed social capital; the average social capital index is over 2 and under 2.5. Conditionally it is Type 2 . The third group includes respondents with capital levels over 2.5 and under 3 , which corresponds to the high-level closed capital. Conditionally - Type 3. Social capital over 3 and under 3.8 corresponds to the fourth type which is open social capital. Conditionally - Type 4. Social capital over 3.8 is the fifth type, which corresponds to high-level open capital. Conditionally - Type 5 .

The indicator model of social capital was empirically tested in the Vologda Oblast (region). The Vologda Oblast is a Russia's constituent entity located in the North-West of the European part of Russia and is part of the Northwestern Federal district. Its administrative center is the City of Vologda. The Vologda Oblast ranks 5th in territory size (145.7 thousand $\mathrm{km}^{2}$ ) among six regions of the Northern Economic Region and 27th in Russia, 42nd - in population (1245.5 thousand people) in Russia as a whole, and 39 th - in level of urbanization (share of urban population - 68\%). The Vologda Oblast has a rich history. The regional center is the City of Vologda, the same age as Moscow with its history since 1147. The Vologda Oblast is a typical Russian region, as a rule, reflecting the main Russian trends.

The first sociological survey in the Vologda Oblast aimed to study social capital was conducted in June 2016. The survey was based on interviews at the place of residence on representative multi-stage sample limited by socio-demographic characteristics. 1,500 people were interviewed. According to the survey results the survey tools were improved. The second population survey in the Vologda Oblast was held in summer in 2017.

All respondents were divided into the following groups according to the obtained index:

Type 1 - extremely low level of social capital (SC)

Type 2 - low level of SC

Type 3 - average level of SC

Type $4-$ SC level above average

Type 5 - high level of SC

It should be noted that among the residents of the Oblast people with an average level of social capital, belonging to types 3 and 4 types prevail. People with a high level of social capital make up only $7 \%$. (Figure 2)

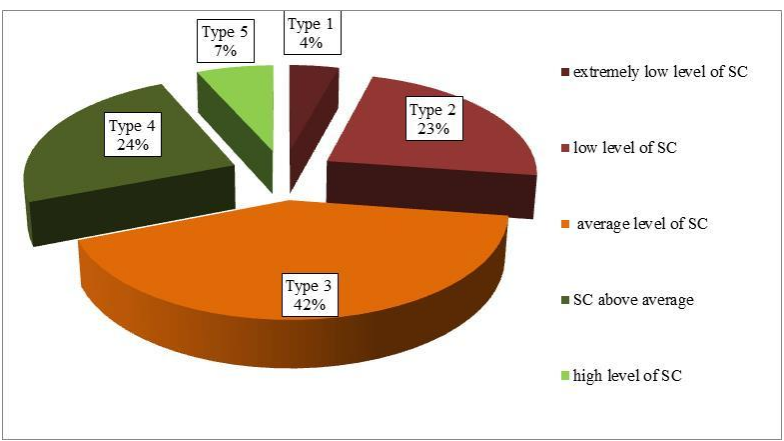

Figure 2. Population structure by level of social capital 
To demonstrate the essence of people's distribution into clusters by level of SC development let us compare the answers to a number of questions depending on the level of social capital. More than half of people with a high level of social capital, i.e. Type 5, note that they influence the situation at work. Among people from groups with type 4 and type 3 of SC - only 32\% and 14\% respectively. More than a half of those who do not possess SC do not influence the situation at work (Tab. 1). Among people with a high level of social capital $67 \%$ are ready to unite with other people, the same share in other clusters is much smaller.

Table 1. Distribution of answers to the question "Do you personally have any influence on the situation at work? Depending on group of social capital.

\begin{tabular}{|l|c|c|c|c|c|}
\hline & Type 1 & Type 2 & Type 3 & Type 4 & Type 5 \\
\hline Completely & 0 & 7 & 14 & 32 & 57 \\
\hline To a large extent & 5 & 18 & 38 & 41 & 40 \\
\hline To a small extent & 26 & 28 & 24 & 12 & 0 \\
\hline I do not have any influence & 56 & 33 & 15 & 3 & 2 \\
\hline Not sure & 13 & 14 & 10 & 11 & 2 \\
\hline Influence index & $\mathbf{- 1 . 3 3}$ & $\mathbf{- 0 . 6 2}$ & $\mathbf{0 . 1 1}$ & $\mathbf{0 . 8 7}$ & $\mathbf{1 . 5}$ \\
\hline
\end{tabular}

Table 2. Distribution of answers to the question "There are people who are ready to unite with other people to solve problems and those who are not willing to do it. What type of people do you belong to?"

\begin{tabular}{|l|c|c|c|c|c|}
\hline & Type 1 & Type 2 & Type 3 & Type 4 & Type 5 \\
\hline I definitely belong to those willing to unite & 3 & 5 & 16 & 28 & 67 \\
\hline I am possibly willing to unite & 15 & 18 & 39 & 56 & 22 \\
\hline I am not willing to unite & 26 & 31 & 17 & 5 & 3 \\
\hline I am definitely not willing to unite & 36 & 15 & 3 & 1 & 3 \\
\hline Not sure & 21 & 31 & 25 & 12 & 5 \\
\hline Index & $\mathbf{- 0 . 7 7}$ & $\mathbf{- 0 . 3 3}$ & $\mathbf{0 . 4 9}$ & $\mathbf{1 . 0 5}$ & $\mathbf{1 . 4 5}$ \\
\hline
\end{tabular}

The level of social capital is largely determined by the level of trust. According to surveys, the level of both inter-personal and institutional trust in the Vologda Oblast is not high. $57 \%$ of respondents note that one can now trust only closest friends and relatives, $22 \%$ believe that no one can be trusted. The level of trust in political institutions (with the exception of trust in the President of the Russian Federation) is also very low. Only $18 \%$ of respondents trust political parties, 34\% - trust the State Duma.

Another important indicator of social capital is involvement in social networks, associations, and public organizations. $70 \%$ of respondents note that they are not members in any official public organizations.

\section{Conclusion}

Thus, we recognize the concept of sustainable development as one of humanity's highest priority. The triad approach to interpreting sustainable development through unity of environmental, economic and social aspects is the methodological basis 
for research in this area. We believe that the social component plays an important role in this unity. The social component of sustainable development is focused on people, on maintaining the sustainability of social and cultural systems, and promoting social integration. Sustainable social development implies the involvement of the society in all processes forming social environment. In this context, a close link between sustainable development and social capital has been detected.

The cluster approach as a reflection of the trend in regionalization of social capital formation mechanisms has proved to be productive in developing the concept of sustainable development. The most important objective in managing modern socioeconomic systems, including the regional ones, is to achieve balanced sustainable development which provides long-term conditions for stable economic growth providing a high quality of life. A special role in addressing this problem belongs to the region's social capital. Territory's development in new conditions should be focused on activating internal non-material social resources. At the regional level, the foundation for sustainable development may be the increasing role of the civil society, growing social ties, and regional population's inclusion in the process of solving social problems through the institutions of civil society. At present, the strategic goal of the territorial development policy should be creating and development of social relations focused on territories' self-development, i.e. forming social capital.

The concept of social capital in science is underdeveloped and has ambiguous interpretations. We consider social capital as the presence of networks of social relations characterized by standards of trust and reciprocity, level of people's involvement in them, and, ultimately, as external effects useful for the society and social groups (in our context - for a region). Social capital serves as a factor in ensuring sustainable social development of a territory. It can be viewed as a special type of resource of a region, which combines the properties of economic and social resources.

Studying social capital in Russia is extremely relevant, but the research is still fragmented and limited by lack or unavailability of reliable data. The question of collecting sufficient data is one of the problems of correct measurement, and hence definition of measurement objects and a set of measurable indicators. Measuring social capital is a complex task as social capital is intangible and is not always directly observable.

The article proposes an indicator model of sociological measurement of social capital. Empirical studies of social capital in the Vologda Oblast based on the indicator model helped divide the population into five groups by level of their social capital.

Of course, the assessment of social capital obtained by the sociological survey should be supplemented by analysis of the region's economic indicators. But the sociological assessment also shows the heuristic possibilities of the construct of social capital. We have proved the validity of the indicator model of social capital and the index method in its measurement.

It is obvious that with a sufficient supply of social capital, the need for state regulation of the economy and society is reduced. In particular, trust, exchange of information on social networks, and business and labor ethics increase the efficiency of investment, companies and markets. In this case, the economy has less need of formal institutions. With a sufficient supply of social capital, the society can partially substitute the state in the main area of the latter's scope of authority - provision of public goods - which will 
ensure the region's sustainable development.

The practical relevance of the study lies in the possibility of using its results and recommendations in the process of developing regional sustainable development strategies. The proposed method of sociological measurement of social capital can be applied in further studies.

\section{References}

Afanasev, D.V., Guzhavina T.A., Mekhova A.A. (2016). Sotcialnyi kapital v regione: k voprosu izmereniia i postroeniia indikatornoi modeli [Social Capital in a Region: Revisiting the Measurement and Building of an Indicator Model]. Ekonomicheskie i sotcialnye peremeny: fakty, tendentcii, prognoz [Economic and Social Changes: Facts, Trends, Forecast], 6 (48), 110-125. (In Russian).

Becker, G.S. (1975). Human Capital. A Theoretical and Empirical Analysis, with Special Reference to Education. Second edition. N.Y.: Columbia University Press.

Beugelsdijk, S., Smulders, S. (2009). Bonding and Bridging Social Capital and Economic Growth Center. Discussion Paper. № 27, 1-39.

Boldov, O.N. (2010). Vzaimosvyaz' ekonomicheskogo rosta i dinamiki natsional'nogo bogatstva s uchetom neveshchestvennogo kapitala [The Correlation between Economic Growth and National Wealth Performance regarding Non-material Capital]. Problemy prognozirovaniya [Issues of Forecasting], 2, 21-32. (In Russian).

Bourdieu, P. (2001) Prakticheskii smysl [Practical Reason: On the Theory of Action]. Saint Petersburg: Aleteiya. (In Russian).

Bourdieu, P. (2002) Formy kapitala [Forms of Capital]. Ekonomicheskaya sotsiologiya [Economic Sociology], vol. 3, 5, 60-74. Available at: https://ecsoc.hse.ru/data/2011/12/08/1208205039 /ecsoc (In Russian).

Coleman, J. (1994). Foundations of Social Theory. Cambridge, MA: Harvard University Press.

Fisher, I. (2007). The Nature of Capital and Income. Cover Copyright. Cosimo classic.

Guzhavina, T.A., Vorobieva, I.N. Primenenie faktornogo analiza pri izmerenii sotsial'nogo kapitala [Application of Factor Analysis in the Measurement of Social Capital]. Sotsial'noe prostranstvo [Social Area], 4 (11). Available at: http://sa.vscc.ac.ru/article/2377. (In Russian).

Jóhannesson, G., Skaptadóttir, U. and Benediktsson K. (2003). Coping with Social Capital? The Cultural Economy of Tourism in the North. Sociologia Ruralis, 43 (1).

Knack, S., Keefer, P. (1997). Does Social Capital Have an Economic Pay-off? A Cross Country Investigation. Quarterly Journal of Economics, 112.4, 1251-1288.

Marsh, C. (2000). Social Capital and Democracy in Russia Communist and Post-Communist Studies, 33, 183-199.

Marx, K, Engels, F. (1960) Collected Works. Vol. 23. (In Russian). Moscow: Politizdat.

Polishchuk, L.(2011) Sotsial'nyi kapital v Rossii: izmerenie, analiz, otsenka vliyaniya [Social Capital in Russia: Measurement, Analysis, Assessment of Influence]. Gorodskoe upravlenie: Institut munitsipal'nogo upravleniya [Municipal Government: Institution of Municipal Government], 6, 83-90. (In Russian).

Polishchuk, L., Menyashev, R.Sh. (2011). Ekonomicheskoe znachenie sotsial'nogo kapitala [Economic Significance of Social Capital]. Voprosy ekonomiki [Economic Issues], 12, 46-65. (In Russian).

Porter, M.E. (2006). Konkurentsiya [Competitive Strategy]. Translated from English. Moscow: Vil'yams. (In Russian).

Putnam, R. D. (2001). Bowling Alone: The Collapse and Revival of American Community. N.Y.: Touchstone Books by Simon \& Schuster. 2001.

Shapovalova, T.V. (2013) ВПлив соціального капіталу на економічне зростання [Influence of Social Capital on Economic Growth]. Економічний аналіз: зб. наук. праць. [Economic Analysis], vol. 14, 1, 167-175. Ternopil: Ekonomichna dumka. (In Ukrainian). 